\section{Application ProteGo Stop Covid - Could it have been an opportunity to prevent Covid-19 spreading?}

\author{
Julia Banasiak \\ University of Economics in Katowice, Poland \\ https://orcid.org/0000-0002-8602-1165
}

Political Preferences

2021, vol. 29: 47-59

journals.us.edu.pl/index.php/PP

Submitted: 01/12/2021

Accepted: 22/12/2021

DOI: $10.31261 /$ polpre.2021.29.47-59

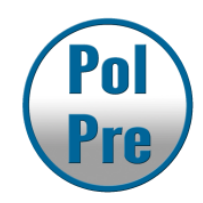

\begin{abstract}
:
This article has several aims. The first one, based on analysis of real-life data of the first Norwegian contact tracing app "The Smittestopp app", is to show how digital contact tracing apps work and their function and possible impact in COVID-19-crisis. I mainly focused on apps designed to automatically tell users orland public health officials whether somebody has potentially been exposed to COVID-19. What are the factors that could impact its reception from the public opinion? The second one is to present the result of automated contact tracing apps that are backed by national governments in selected countries. And finally, I would like to look at the social, political, economic, and psychological circumstances of launching the Polish application "ProteGo Stop Covid". I characterize the process and conditions that occurred when the Polish government was working on it and try to answer the question if it were possible to implement this process more effectively.
\end{abstract}

Keywords: contact tracing apps, COVID-19, STOP COVID-ProteGo Safe, Ministry of Digital Affair

\title{
Introduction
}

In late December 2019 an abnormal form of mysterious pneumonia occurred, characterized by fever, dry cough, and fatigue, and occasional gastrointestinal symptoms, health threatening medical service in China. Shortly after the first confirmed cases outside of the country, scientists from all over the world began research into factors of disease as well as measures to catch it. On $11^{\text {th }}$ of February 2020 at the media briefing, the Director-General of the World Health Organization announced "COVID-19" as the name of this new disease (WHO, 2020).

Since that moment it has become clear that pandemic is more than a matter of health system workers, nonetheless their effort is incredibly important, but it's a prominent social, cultural and political phenomenon. In the time of crises, society expects governments to take bold actions. Most of the time those actions are typically carried out in the private sector or citizens' standard of comfort. How local and state authorities responded to the pandemic can influence 
elections, who engages in political discussion, who registers to vote, who votes, and how they vote. Trust in institutions may alter because of perceptions of government response and performance during the crisis, so a pandemic like Covid-19 undoubtedly is a huge threat, but it might also become an opportunity. Therefore, not only was it necessary to diligently track the outbreak of COVID-19, but also Governments were forced to undertake a broad range of unprecedented interventions in order to provide as much protection for their citizens as it was possible. The simplest form of the measures that so far have been taken to stop the spread of the disease were lockdowns people had to undergo in most of the countries. Another popular action taken by authorities in many countries in order to stop the pandemic was launching digital contact tracing apps. The MIT Technology Review’s 'Covid Tracing Tracker' listed around 50 globally, 22 in the European Union (Johnson, 2020).

The aim of the paper herein is to explore the element that is crucial to effective uptake of contact tracing apps in the communities, with the focus on how effective this technology is compared to the uptake level. In this context the article will try to answer the following question: Could it have been possible for the Polish government to reach higher uptake numbers, that would help to sustain the control of the epidemic. The aim of this comparative research is to determine whether significant differences existed between Qatar, Singapore, Italy, Switzerland, Germany, the Netherlands and Poland, that led to radical margent in the final effect that brought implementation of contact tracing apps in those countries. In order to assess the effectiveness of contact tracing applications each example was verified by the analysis of the political environment and demographic data that are representative for each country mentioned here. The analysis is based on a comparative study. The analysis covers data gathered from the period of the covid outbreak until now. The conclusions were based on effectiveness of contact tracing applications measured by total cases and deaths per million people.

\section{Technology of digital contact tracing apps}

Because of a "tech-solutionist" point of view- the concept that technological products and services can solve even the most complicated problems of the humankind, by simplifying complex social phenomenon and ambiguity concerning the forms of algorithms- and a need for alternatives to lockdown measures that limit citizens freedom and strain the economies and scholar systems (Morozov, 2014). Therefore, high hopes have been placed by both local administrations and national governments in apps and devices which aim was to suppress the 
outbreak of the COVID-19 through automation. After more than a year since the launch of the first such app, findings and evaluations on the effectiveness and impact of digital contact tracing apps in actual responses to the COVID-19 pandemic differ so much that it is almost impossible to present an explicit outcome. Data varies significantly between countries and studies. Moreover, it was hardly workable to define the term of "effectiveness" in the above-mentioned situation of a digital contact tracing app.

In the article "Digital contact tracing, community uptake, and proximity awareness technology to fight COVID-19: a systematic review" George Grekousis and Ye Liu show that digital contact tracing can be viewed as both "the number of contacts identified through digital contact tracing", and - as they prefer to do - "the actual effect of digital contact tracing on reducing the effective reproductive number, or the number of infected individuals" (Grekousis \& Liu, 2021). The choice of interpretation of this technology leads to very diverse conclusions that are drawn when asking about its effectiveness.

In this paper, to assume definition of possible effectiveness I used research that provides actual contact data set, collected during the launch of the first Norwegian contact tracing app “The Smittestopp app" in the Spring of 2020 by Ahmed Elmokashfii et al. (2021). The authors emphasize this technology can be used as a supplement to manual tracing and other measures, so digital tracing can be helpful in controlling the pandemic. Presented findings can help understand pandemic and society influenced by it, and thus, support public health policies in the future. This analysis illustrates that digital contact tracing apps are potentially able to help prevent COVID-19 and other disease outbreaks, especially the ones related to highly connected individuals and super spreading events (Elmokashfi et al., 2021).

Fig. 1: The impact of app uptake on the spread of SARS-CoV-2.
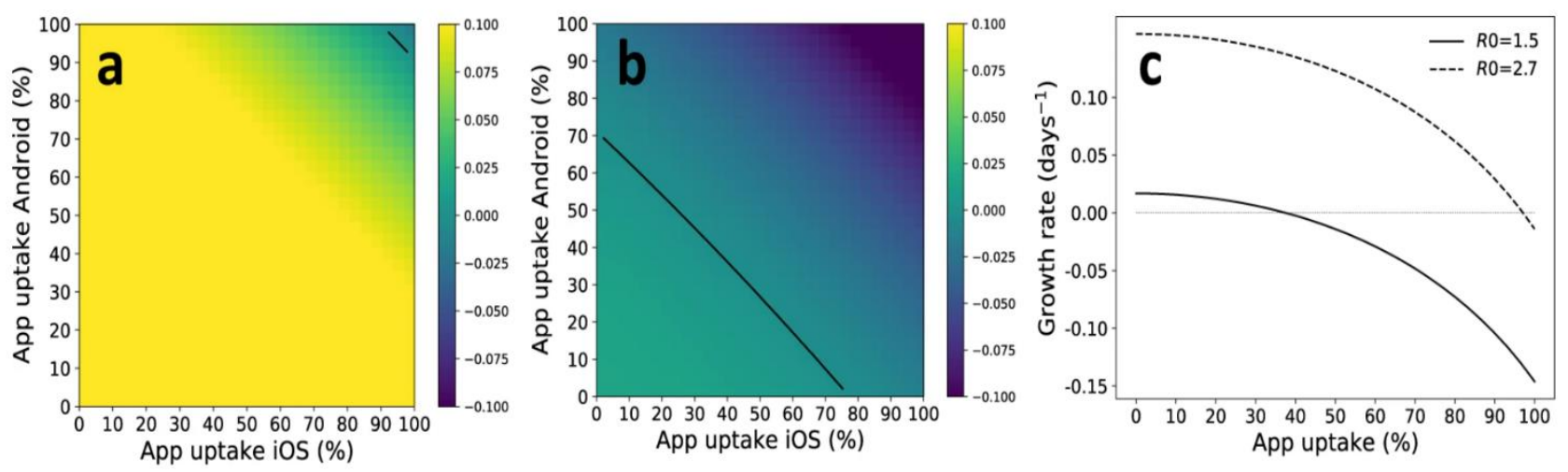

Source: Elmokashfi, A., et al. (2021). 
"The plots show the estimated growth rate $\mathrm{r}$ as a function of app uptake among Android and iOS users. We have assumed $90 \%$ efficacy of case isolation and a 4 h delay of both case isolation and contact quarantining. picture A Shows the situation for $\mathrm{R} 0=2.7$ and $\mathrm{B}$ shows $\mathrm{R} 0=1.5$. Figure $\mathrm{C}$ Shows the same data, but assuming identical app uptake among iOS and Android users. Note that R0 denotes the initial reproduction number of the pandemic, which is the expected number of new cases that are caused by an infected individual." (Elmokashfi et al., 2021). First figure shows that with number $\mathrm{R} 0=2.7$. app will not be a significant change in pandemic growth. However, the situation is completely different assuming the case of R0=1.5, which is more representative of a current situation with other controlling measures in use. In this case, the uptake at $40 \%$ level sustains the control of the epidemic and allows for the achievement of a decline in the number of cases.

According to data published by authorities the best representatives that support upper stated thesis are countries like Qatar- 91\% level of uptake and Singapore- 86\% level of uptake but it's an exception to the global trend and in both countries its use is mandatory (in Qatar its mandatory to install by residents, in Singapore check-ins must be performed using an app or special token in places where visitors are exposed to "higher throughput" of people, such as malls, workplaces, places of worship, etc.). Other countries show that the uptake of applications is drastically different, when the use of apps is not mandatory. Among these countries there are mostly European countries such as: Italy (31\%), Switzerland (42\%), Germany (47\%), the Netherlands (32\%) and Poland (6\%). As the authors of the document quoted before, it is assumed that manual contact tracing identifies all non-random contacts. However, the number of downloads has not necessarily corresponded with the effective contact tracing responses in either country.

Experts from Finland (49\% uptake) claim that the "Korinavilkku" app has not brought many benefits so far (YLE NEWS, 2021). The report by Douglas J. Leith and Stephen Farrell, Trinity College Dublin researchers, focused on analysing six months of data from the Irish “Covidtracker" app (45\% uptake), from October 2020 to April 2021, only to find that, "Over that period only $25 \%$ of the expected number of tested-positive app users uploaded keys, which are required for that user's app instance to fulfil its primary function as part of the contact tracing system. For recent months we see only 15\% of expected uploads" (Leith \& Farrell, 2020).

The data supports conclusion presented by George Grekousis and Ye Liu that effectiveness of digital tracing depends strongly on app downloads, (however significant results 
are possible to achieve from moderate uptake numbers) but not only, because "the success of digital contact tracing depends on a complex interplay of app uptake in the community, proximity awareness technologies, and public's trust" (Grekousis \& Liu, 2021).

One of the factors mentioned here can be influenced by authorities providing and managing information not only about apps but also the Pandemic in a way that will encourage society to trust them and their solution. One of the crucial aspects of managing the COVID-19 crisis was utilizing data and information systems. These efforts were seen in every country fighting virus, among them, Poland was not an exception. Information policies are different in every country mostly because of the degree of centralization but also social trust. Albert Meijera and C. William R. Webster (2020) in their article assume that we can distinguish among the countries where official information policies connected to COVID-19 were highly questioned by the media and society (the United States, Brazil, Mexico) and countries where due to strong institutional dominance departures from official policies were not possible (Singapore, South Korea, China) as well as countries where we could see democratic models of information policies, which were mostly accepted by the media and society, but at times criticised (Canada and most European countries including Poland).

Each information system should be considered as an element of wider actions with political and symbolic meaning. Research shows that there is no better or more effective solution of creating informative narrative and decentralization does not always guarantee credibility, at the same time centralization of information can result in high credibility, such as the example of Singapore. Credibility of governments information policies is connected mainly to historical and cultural factors in specific countries. In the face of COVID-19 authorities in each country launched many actions which can be included in information policy, such as contact tracing apps and other apps devoted to COVID-19.

It's important to answer the question if those actions have reached all social groups, especially the most vulnerable section of the population. Sometimes information provided by the government could be perceived as too official for certain groups of the society. People tend to use fewer formal sources that are broadcasted by, for example, social media. There often can be found communities that are denying the epidemic or its meaning to the world, these communities are growing and becoming more institutionalized. Every government should take into consideration the way information is formed and evolves so as to take steps in order to increase the level of rationality and trust in public discourse around COVID-19. 
This analysis took into consideration political factors that could influence contact tracing app uptake. According to analysed data one can notice strong correlation between public trust in government and application uptake (OECD, 2021).

Fig.2: The relationship between trust in government and government contact tracing application uptake

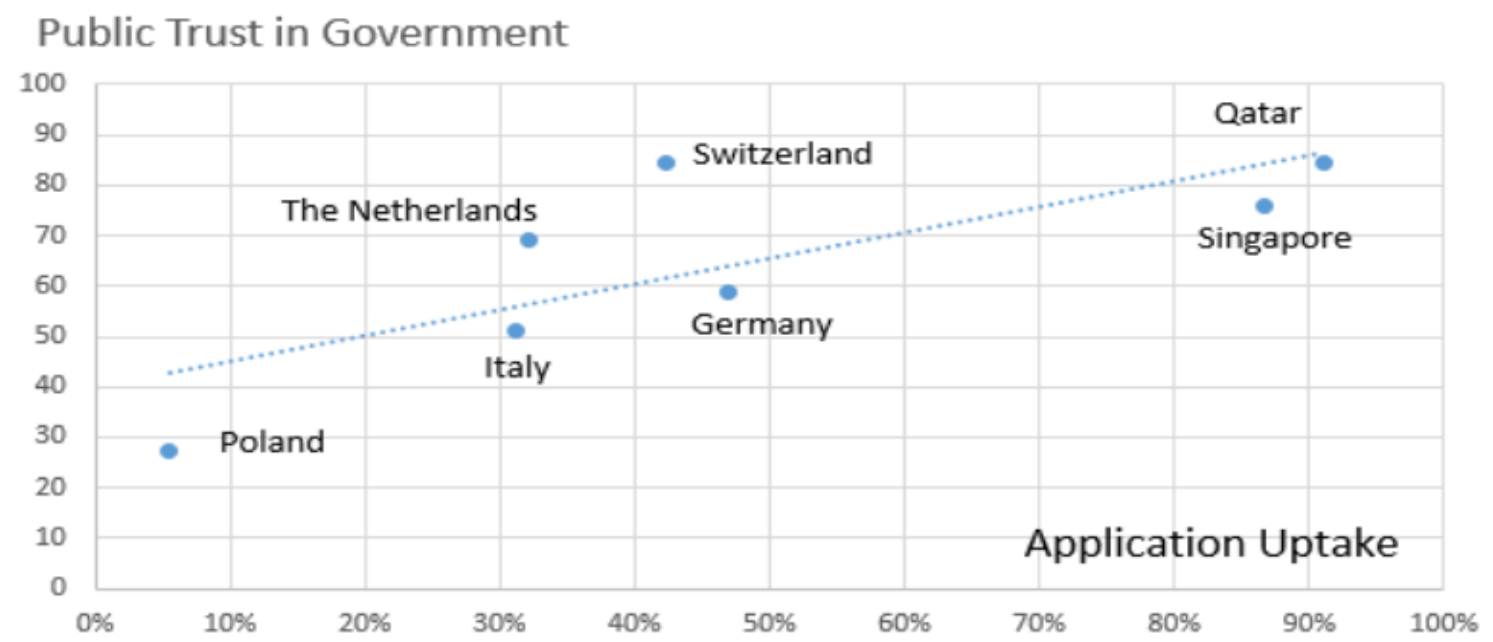

The lowest level of application uptake is shown in Poland, where simultaneously the level of public trust is drastically lower than in other considered country. One can also see a trend that shows higher uptake level in countries where the app is mandatory, the public trust in government is high. Another factor that might influence the described phenomenon is the political system. In European democratic countries the rate of uptake does not exceed 50\%. In monarchy countries (like Qatar) and where the political system has been dominated by one party (Singapore) the level of uptake drastically differs.

\section{Tab.1: Gathered demographic and political parameters for chosen countries}

\begin{tabular}{|c|c|c|c|c|}
\hline Country & Political system & $\begin{array}{l}\text { The median } \\
\text { age }\end{array}$ & $\begin{array}{c}\text { Rate of } \\
\text { internet } \\
\text { adoption }(\%)\end{array}$ & Application \\
\hline Qatar & Absolute monarchy & 32.3 & 99.0 & Mandatory \\
\hline Singapore & Republic and a parliamentary democracy & 38.2 & 88.5 & Voluntarily \\
\hline Italy & $\begin{array}{c}\text { Parliamentary republic with a multi-party } \\
\text { system }\end{array}$ & 47.3 & 73.3 & Voluntarily \\
\hline Switzerland & Semi-direct democratic federal republic & 43.1 & 88.3 & Voluntarily \\
\hline Germany & $\begin{array}{l}\text { Federal state and a parliamentary } \\
\text { democracy }\end{array}$ & 45.7 & 94.0 & Voluntarily \\
\hline The Netherlands & Parliamentary representative democracy & 43.3 & 95.0 & Voluntarily \\
\hline Poland & $\begin{array}{l}\text { Republic and a parliamentary democracy } \\
\text { with a parliamentary and cabinet system }\end{array}$ & 41.7 & 84.5 & Voluntarily \\
\hline
\end{tabular}


Not only the political system is an important factor, but demographic parameters also influence uptake of contract tracking apps. The digitalization of society is also a necessity in introducing technological solutions. Among all analysing countries the level of digitalization is high, the lowest level is recorded in Italy and Poland. Another important aspect is the median age in society. Countries with the highest uptake level simultaneously show lowest median age.

The effectiveness of contact tracing applications measured by total cases of COVID-19 and deaths per one million people show that high uptake rate corresponds especially with lower death rates. It also makes an impact by lowering total cases among citizens (Worldometer, 2021).

Tab. 2: Comparison of uptake of contract tracking apps, total cases and deaths in chosen countries

\begin{tabular}{cccc}
\hline Country & Uptake & Total cases/1M pop & Deaths/1M pop \\
\hline Qatar & $91.00 \%$ & 88480 & 219 \\
Singapore & $86.58 \%$ & 46931 & 139 \\
Italy & $31.25 \%$ & 94118 & 2267 \\
Switzerland & $42.30 \%$ & 139615 & 1386 \\
Germany & $46.99 \%$ & 83369 & 1320 \\
The Netherlands & $32.15 \%$ & 178955 & 1206 \\
Poland & $5.53 \%$ & 107314 & 2497 \\
\hline
\end{tabular}

Source: Worldometer (2021).

Comparing five, mentioned in this paper, European countries with countries where the level of uptake is significantly higher (Qatar and Singapore) the death rate in Qatar and Singapore is $90 \%$ lower. Impact of application uptake is also visible in total COVID-19 cases, but the total effect is not so significant.

\section{Polish contact tracing app STOP COVID-ProteGo Safe}

Work on the Polish version of contact tracing app started in March 2020, by IT specialists voluntarily working to bring technology supporting the fight against the spread of the virus (Romanów, 2021). First version was released in March the same year; it was mostly a collection of information about COVID-19 and health diary. Work on an app that would focus on contact tracking features was initiated by the Ministry of Digital Affairs (STOP COVID - ProteGO Safe, n.d.). The version based on this technology was launched at the end of April 2020. This app was heavily criticized by IT experts and civil society organizations, mostly because of its centralized 
system and scruples about possible privacy issues (Szymielewicz et al., 2020). There have been growing concerns about the functioning of this kind of apps not only in Poland but also in other states. These concerns were reasonable when we look at the mechanisms used in some of these apps. Some apps were seen as threatening civilians' privacy even though experts were assuring that apps are safe. In March 2020 a group of Polish non-governmental organizations experts prepared an appeal in which they formed the most important rules to follow while projecting technological devices and apps in agreement with RODO and bringing social trust. Those were:

- Minimization and data correctness

- Limiting the duration of data keeping

- Data storage on citizens devices

- Safety, encryption and sensitive data

- Legible information for citizens

- Code availability and algorithms legibility

- Public control over tools (Napierała, 2020).

First App released by the Ministry of Digital Affair (then under the name ProteGo Safe) in contrast to the model proposed by Google and Apple generated user identifiers by downloading data from the Ministry's server while they were not generated locally on users' devices. In practice it meant that identifiers which in theory were supposed to be anonymous could be linked to an IP address-which enables app administrators to track a specific person, as the government servers are able to request this type of data from operators. What was more, if one would mark themselves as infected, they would have to verify their phone number, so it breached privacy even though the app was advertised as "data-free" (Potiuk, 2020). Together with releasing this version of the app the Ministry of Development introduced a plan of loosening restrictions in the form of privileges for persons using the app (10\% higher number of people that can be admitted to the place if they have the app, queuing privileges if there are no crowds in the shop, need to place a device that register by Stop COVID (then ProteGo) entrance to the facility or printing QR code generated from app to be scanned by customers).

Those propositions met with social discontent and protests due to which the Ministry of Development deleted the proposal from their website. As a response to social pressure in April it was confirmed that there was going to be a new version of the application, based on Exposure Notification principles (Serwis Rzeczypospolitej Polskiej, 2020). This solution released in June 2020 works on systems that constantly broadcast random IDs over the Bluetooth channel. At the 
same time the surroundings are being scanned and IDs of other devices within a distance of a few meters are remembered. Devices registered presence of one another, but the IDs broadcasted were random and changed every quarter-hour, so in this variant of the system users remained anonymous. In case of diagnosis of COVID-19 owner of the device who provided this data would receive a PIN code that would allow them to send their uploaded "sick IDS" to the Ministry's server. Automatically other user devices would check whether they had been in contact with the sick person in the past two weeks by downloading the "sick IDs". In that situation the user got a notification about contact with someone who had been diagnosed positively for COVID-19. A person who tested positive for COVID-19 might voluntarily upload a data to send an anonymous warning to other users of the STOP COVID-ProteGO Safe.

2.098 million - that's the number of downloads of the government application STOP COVID -ProteGO Safe from the end of April 2020 to the end of July 2021 it's impossible to precisely estimate how many users are still active and use the application regularly because of the earlier mentioned the system secures users anonymity (Cronin et al., 2021, 66-69). In this period only 7,042 users uploaded special code PIN that was brought from sanitary-epidemiological station to confirm COVID-19 infection. Putting these numbers in perspective up to today (21.11.2021) 3.46 million of cases were confirmed in Poland from approximately 37.95 million citizens. Assuming that the percentage of cases confirmed in Poland is equal to the percentage of app users who got positive test results, less than 0,5 percent of sick users shared this information with the application.

The cost of development and operation of the STOP COVID-ProteGO Safe application estimates around 5,944,344 PLN (about 1,316,664 EUR) (Joński, 2020). In November 2021 based on the data cited here, it can be stated that potential of such technologies, especially in application STOP COVID-ProteGO Safe were not used at all in Poland. Portal Spiders Web on 5th August 2021 published the article in which it declares that Digital Affairs - Chancellery of the Prime Minister (used to be the Ministry of Digital Affairs) admitted that there had been an inquiry sent to the Main Sanitary Inspectorate to consider whether it was worth to cease STOP COVIDProteGO Safe app (Czubkowska, 2021). The app is still working.

One of the reasons for the above was certainly the initial criticism and heated debate that arose in April 2020. Back then, many IT experts and programmers expressed their concerns and distrust in it. Even though the Ministry of Digital Affair joined the discussions with critics, set up an expert group of ProteGo Safe (Klicki \& Szymielewicz, 2020) and presented a comprehensive 
privacy policy risk analysis for protection of personal data, FAQ and report on security audit the first impression that was presented to publicity left a non-removable connotation (Serwis Rzeczypospolitej Polskiej, n.d). Research published by the Organisation for Economic Cooperation and Development shows that in 2020 trust in the Polish government was declared by $27 \%$ of respondents. (OECD, 2021)

Promotional campaign launched on Twitter in June 2020 which might have worked with the younger part of the population that has easier access and greater understanding of technology proved to be a huge failure as it was conducted by posting tweets using fake accounts. Dry statements posted with fake signatures of doctors or professors were quickly pointed out by the users "fluent" in social media language. Instead of encouraging, the whole campaign became more of a scam or just a joke. Instead of separating this action from political accounts, the same bots that were used in the presidential campaign the politicians of the Law and Justice (PiS) (Kardys, 2020).

Some people also found the first version of the name of the app "ProteGO" confusing and not easy to decipher, especially older users, who were supposed to be the main targeted group. As a name itself it means nothing to the average internet user, it sounds unfamiliar, it is difficult to be repeated by the older users. It had not been until the fall of 2020 when the act of rebranding and adding more understandable part "STOP COVID" took place.

Another great concern for app administrators was fake news that started to arise around apps linking apps to protests that had been taking place all over Poland since $22^{\text {nd }}$ of October 2020 that were reaction to the verdict of the Constitutional Court. Even though the app at that moment could not serve its purpose (it did not use geolocation data, did not track users and did not have access to any files and data on users' phone) post published on Twitter went viral (on $27^{\text {th }}$ of October 2020 it had 2,800 retweets and 2,700 likes) and it warned people that the whole purpose of the application was "to send everyone from strike to quarantine and by that silence everyone" (Julus, 2020). As mentioned before, the campaign on twitter shows the administrator of that app had a problem with communicating information about the app to the younger part of the generation. To put the whole issue in perspective, the answer to this tweet made by the profile of Digital Affairs - Chancellery of the Prime Minister has 9 retweets and 59 likes. People, even if they did not believe in this conspiracy theory, started to worry and became suspicious which resulted in general distrust. 
The plan of the Ministry of Development I have mentioned before which aimed at loosening restrictions in the form of privileges for persons using the app was received in Poland as categorization between better and worse citizens. First narration that was used to talk about ProteGo-STOP COVID following global trends suggested that the app by itself could stop the pandemic. Today we know that the belief in the agency of those apps was naive. We have been taught a lesson that instead of statements: "Everything it's up to you" (Polish: Wszystko w twoich rękach) there should have been a greater focus on showing people how effective and selfprotective it is to use digital contact tracing (Serwis Rzeczypospolitej Polskiej, 2020). It seems like now the apps themselves and the way they are managed have gone two different directions.

\section{Conclusion}

This technology is a meaningful support in suppressing the pandemic of COVID-19. Analysed examples of countries with high uptake rate of contact tracking applications emphasize advantages of this solution. First of all, the political conditions are most important, especially trust in government. Demography of society also makes an impact, but it is not so significant. The most important result of effective implementation is lowering death rates in countries.

Taking into consideration data gathered in this research, the introduction of the Polish equivalent STOP COVID-ProteGo Safe from the beginning was challenging. Poland in comparison to mentioned countries has significantly worse records of factors mentioned as crucial. Except for the main factors, implementation of the app was connected with many faults, imperfections and questionable decisions. As examples in other fields show, new technologies might yield different results. Highly developed digital banking, other government solutions supporting health systems (such as for example online prescriptions) might suggest that citizens in Poland are ready to use new technologies and innovations. This exact application is still meeting strong resistance and hate on social media. Regarding circumstances at the moment of launching the app in Poland (cultural, social, economic, political) its success was highly dependable on a form of communicating about it. In these social surroundings the must have been a comprehensively prepared communication strategy. Government could have cooperated more closely with the media. Lack of trust in the government and low-quality information policy resulted in failure. Authorities had the possibility and tools to prepare society for innovation. Analysing the process of implementing and functioning of this app on the market one can assess those actions concerning communication were delayed and did not have cohesive structure. It is 
important to remember that at that moment every action taken by the government was a race against time. As Marek Zagórski, former Minister of Digital Affairs, said in interview in 2020: "Referring to controversies, I have to admit we met with unjust accusations, when it comes to this technology. We started work on ProteGO Safe as one of first countries in Europe, in situation, when no one did not have yet defined vision of how this application should work"1 (Kozłowski, 2020).

Undoubtedly, creating STOP COVID-ProteGo Safe was possible thanks to cooperation and high investment of people from many different groups, among them voluntary workers, yet, it proved to be insufficient. There has not been enough information policy, and the political surrounding was unfavourable to create a safe environment in which those efforts could bring an actual result to COVID-19 crisis. Previously mentioned mistakes enabled sceptics to increase disinformation work, their narration turned out to be more successful than timid centralized authorities' information.

\section{References:}

Cronin, O., Izdebski, K., Katchaounova, A., Laanpere, L., \& Laufente, R. (2021). Do EU Governments Continue to Operate Contact Tracing Apps Illegitimately? The Civil Liberties Union for Europe.

https://www.bghelsinki.org/en/reports/do-eu-governments-continue-to-operate-contact-tracing-apps-illegitimately

Czubkowska, S. (2021, August 5). Z polskiej aplikacji do walki z COVID-19 skorzystało tylko 7 tys. osób. Kosztowała miliony, teraz jest w powolnej agonii. Spider's Web. https://spidersweb.pl/plus/2021/08/aplikacjaprotego-covid-pandemia

Elmokashfi, A., Sundnes, J., Kvalbein, A. et al. (2021). Nationwide rollout reveals efficacy of epidemic control through digital contact tracing. Nature Communications, 12, 5918. https://doi.org/10.1038/s41467-021-26144-8

Grekousis, G., \& Liu, Y. (2021). Digital contact tracing, community uptake, and proximity awareness technology to fight COVID-19: a systematic review. Sustainable cities and society, 71, 102995.

https://doi.org/10.1016/j.scs.2021.102995

Johnson, B. (2020, December 16). The Covid Tracing Tracker: What's happening in coronavirus apps around the world. MIT Technology Review. https://www.technologyreview.com/2020/12/16/1014878/covid-tracing-tracker/

Joński, D. [@Dariusz_Jonski] (2020, October 28).BUM Zapytaliśmyz@MichalSzczerba o aplikacje Stop COViD ProteGO Safe (koszty ponad 5 mln zł!). https://twitter.com/Dariusz_Jonski/status/1321397111049625600

Julus. [@duzemysli] (2020, October 26). NIE POBIERAJCIE APLIKACJI STOP COVID [Image attached]. https://mobile.twitter.com/duzemysli/status/1320701247431860225

Kardys, W. [@WojtekKardys] (2020, June 9).Sprawdzitem ten hasztag \#ProteGo i takjakMikotaj@Buszkers zauważyt - wszystkie tweety od konto założone w czerwcu 2020 roku. https://twitter.com/WojtekKardys/status/1270348403092918272

${ }^{1}$ Original: "Odnosząc się do kontrowersji to muszę przyznać, że spotkaliśmy z kompletnie niesprawiedliwymi zarzutami, jeśli chodzi o to rozwiązanie. Pracę nad ProteGO Safe rozpoczęliśmy jako jedno z pierwszych państw w Europie, w sytuacji, w której nikt nie miał do końca sprecyzowanej wizji jak taka aplikacja w ogóle powinna wyglądać." 
Klicki, W., \& Szymielewicz, K. (2020, June 8). ProteGO Safe: czy państwo zasłuży na zaufanie obywateli? Fundacja Panoptykon. https://panoptykon.org/wiadomosc/protego-safe-czy-panstwo-zasluzy-na-zaufanie-obywateli

Kozłowski, A. (2020, August 8). Minister Cyfryzacji: Zarzuty wobec aplikacji ProteGo Safe są całkowicie nieuzasadnione [WYWIAD]. Cyberdefence 24 . https://cyberdefence24.pl/minister-cyfryzacji-zarzuty-wobecaplikacji-protego-safe-sa-calkowicie-nieuzasadnione-wywiad

Leith, D., \&Farrell, S. (2020). Coronavirus Contact Tracing: Evaluating the Potential of Using Bluetooth Received Signal Strength for Proximity Detection. ACM SIGCOMM Computer Communication Review, 50(4), 66-74. https://doi.org/10.1145/3431832.3431840

LibertiesEU. (2021, June 2). COVID-19 Contact Tracing Apps in the EU: Knowledge Hub. Civil Liberties Union for Europe. https://www.liberties.eu/en/stories/trackerhub1-mainpage/43437

Morozov, E. (2014). To Save Everything, Click Here: The Folly of Technological Solutionism. PublicAffairs.

Meijer, A., \& Webster, C. W. R. (2020). The COVID-19-crisis and the information polity: An overview of responses and discussions in twenty-one countries from six continents. Information Polity, 25(3), 243-274.

Napierała, W. (2020, April 6). Technologia w walce z koronawirusem - 7 filarów zaufania. Fundacja Panoptykon. https://panoptykon.org/7-filarow-zaufania

OECD (2021). General government - Trust in government. OECD Data. Retrieved December 27, 2021, from https://data.oecd.org/gga/trust-in-government.htm

Potiuk, J. (2020, April 30). Możliwość de-anonimizacji danych i odtworzenia grafu kontaktów. Github. Retrieved November 27, 2021, from https://github.com/ProteGO-Safe/specs/issues/123

Romanów, M. (2021, March 22). Jak powstawała aplikacja STOP COVID ProteGo Safe? MobileTrends.pl. https://mobiletrends.pl/jak-powstawala-aplikacja-stop-covid-protego-safe/

Serwis Rzeczypospolitej Polskiej. (n.d.). Dokumenty - STOP COVID - Portal Gov.pl. Gov.pl. Retrieved November, 2021, from https://www.gov.pl/web/protegosafe/dokumenty

Serwis Rzeczypospolitej Polskiej. (2020, June 9). Wszystko w Twoich rękach - pobierz, zainstaluj i korzystaj z aplikacji ProteGO Safe - STOP COVID. Gov.pl. https://www.gov.pl/web/protegosafe/wszystko-w-twoich-rekach-pobierz-zainstaluj-i-korzystaj-z-aplikacji-protego-safe

Szymielewicz, K., Obem, A., \& Zieliński, T. (2020, May 5). Jak Polska walczy z koronawirusem i dlaczego aplikacja nas przed nim nie ochroni? Fundacja Panoptykon. https://panoptykon.org/protego-safe-ryzyka

WHO. (2020, February 11). WHO Director-General's remarks at the media briefing on 2019-nCoV on 11 February 2020. World Health Organization. https://www.who.int/director-general/speeches/detail/who-director-general-sremarks-at-the-media-briefing-on-2019-ncov-on-11-february-2020

YLE NEWS. (2021, March 1). Experts claim few benefits to Covid tracing app, paper reports. YLE News. https://yle.fi/news/3-11814681

Worldometer (2021). COVID Live - Coronavirus Statistics. https://www.worldometers.info/coronavirus/ 